\title{
International Economics of Resource Productivity - Relevance, Measurement, Empirical Trends, Innovation, Resource Policies
}

Originally published as:

Raimund Bleischwitz (2010):

International Economics of Resource Productivity - Relevance, Measurement, Empirical Trends, Innovation, Resource Policies In: International Economics and Economic Policy (7), 2 - 3, pp. 227 - 244. 


\section{Raimund Bleischwitz*}

\section{International Economics of Resource Productivity -}

Relevance, Measurement, Empirical Trends, Innovation, Resource Policies

* Corresponding author, Wuppertal Institute, PO Box 100 480, D-42004 Wuppertal,

Germany. Further affiliations with College of Europe, Bruges/Belgium; Transatlantic Academy, Washington D.C./USA; Schumpeter School for Business and Economics, University of Wuppertal, Germany

E-mail: raimund.bleischwitz@wupperinst.org

Phone: +49-(0)202-2492-256

Fax: +49-(0)202-2492-108 
Raimund Bleischwitz

\title{
International Economics of Resource Productivity
}

\author{
Relevance, Measurement, Empirical Trends, Innovation, Resource Policies
}

Publication in „International Economics and Economic Policy“, special issue on ,, The International Economics of Resources and Resource Policy" (Springer Publisher) 2010 (7), $2-3$, pp. $227-244$.

\begin{abstract}
This paper undertakes a step to explaining the international economics of resource productivity. It argues that natural resources are back on the agenda for four reasons: the demand on world markets continues to increase, the environmental constraints to using resources are relevant throughout their whole life cycle, the access to critical metals could become a barrier to the low carbon economy, and uneven patterns of use will probably become a source of resource conflicts. Thus, the issue is also of relevance for the transition to a low carbon economy. ,Material Flow Analysis' is introduced as a tool to measure the use of natural resources within economies and internationally; such measurement methodology now is being harmonized under OECD auspices. For these reasons, the paper argues that resource productivity - that is the efficiency of using natural resources to produce goods and services in the economy - will become one of the key determinants of economic success and human well-being. An empirical chapter gives evidence on time series of resource productivity increases across a number of economies. Introducing the notion of 'material flow innovation', the paper also discusses the innovation dynamics and issues of competitiveness. However, as the paper concludes, market barriers make a case for effective resource policies that should provide incentives for knowledge generation and get the prices right.
\end{abstract}

\section{Introduction}

Besides the major concern with climate change, it is increasingly evident that the natural resource base is one of the major issues of international environmental economics and policy. This paper argues that resource productivity - that is the efficiency of using natural resources to produce goods and services in the economy - will be one of the key determinants of economic success and human well-being in the upcoming years and decades. Deviating from ongoing political struggle about burden sharing and abatement costs, our paper underlines that international economic policy shall promote

Email: raimund.bleischwitz@wupperinst.org. A previous version has been presented at the ,Shanghai Forum 2010', Subforum on the „Emerging Energy \& Low Carbon Economy: the Engine for Asia Economic Transformation”, May 29 - 31, 2010. I wish to thank the participants as well as Meghan O'Brian for useful comments. 
resource productivity not only as a source of future competitive advantage as well as a pillar for the transition to a low carbon economy.

Using materials more efficiently will allow for grasping more opportunities to save energy along the whole value chain, to save material purchasing costs and to enhance competitiveness. Thus it is clear that a key abatement strategy such as energy efficiency will be enhanced by attempts to use materials more efficiently. In a broader context, moreover, fossil fuels are but one natural resource that is used in societies worldwide. All potential substitutes such as biofuels and renewable energies depend upon natural resources such as land, steel and platinum. Providing these natural resources in the most sustainable manner will thus become a key strategy for climate change abatement as well as for green growth. How industry and economies take up these challenges will become a major issue for economic research.

Our paper starts with an overview of why caring for natural resources is relevant from a sustainability point of view that addresses the whole lifecycle-wide use of resources and thus goes beyond just the supply side. The methodology of material flows is introduced in chapter three. Chapter four compares the resource productivity rates and levels of different economies worldwide. Chapter five analyses the relationship between innovation and competitiveness, and chapter six outlines pillars for a sustainable resource policy.

\section{Why Caring about Resources is Relevant}

Caring about natural resources usually starts with addressing the scarcity of supply. Following findings of geological surveys, however, the Earth's crust contains a resource base that is considered to be sufficient. Many basic materials such as iron ore, bauxite (used for aluminium production), magnesium, sand and gravel (essential for construction minerals) are almost abundantly available. From such a perspective, a general absolute scarcity can hardly be concluded.

On the other hand there are strong reasons to analyse natural resources in a more comprehensive manner (MacLean et al. 2010), which in the end leads to fundamental concerns about their use due to:

1. Increasing demand on world markets

2. Environmental constraints

3. Resource constraints to the low carbon economy

4. Misallocation and uneven patterns of use.

This paper will shortly discuss these issues before it moves on to analysing sustainable resource management. Our perspective follows the fundamental issues of substitutability, technological progress and long-term prosperity that have been the core of resource 
economics ${ }^{1}$ and develops an agenda that moves the issue closer to material flow analysis and international economic policy.

\subsection{Increasing demand on world markets}

Global extraction of natural resource is steadily increasing. Since 1980, global extraction of abiotic (fossil fuels, minerals) and biotic (agriculture, forestry, fishing) resources has augmented from 40 to 58 billion tonnes in 2005. The rapidly increasing demand for resources has led to an unprecedented boost in resource prices, especially during the five years prior to the breakout of the financial crisis in mid-2008. In nominal terms the general commodity prices increased by 300 per cent between 2002 and mid-2008 with prices of crude petroleum and minerals and metals escalating by $400-600$ per cent. Even in real prices new historical peaks were reached in mid-2008 (UNCTAD 2010: 8). The financial crisis has marked a short break to this trend, however extraction and prices have started to soar again.

A recent study reveals that extraction in Asia has doubled over the last 25 years, and extraction growth has been much faster than the global average (Giljum et al. 2010).

Increasing demand cannot only be witnessed for fossil fuels and other energy sources but also for all other categories of natural resources (e.g. metals, construction minerals, biomass).

The expected increase in global population and high economic growth rates will strongly raise extraction and the consumption of materials. Though not many global scenarios address the issue yet, those available anticipate further increases and a total resource extraction of around 80 billion tonnes in 2020 and over 100 billion tonnes in 2030, i.e. more than a doubling between 2000 and 2030. Agriculture and construction are expected to be the most important extractors until 2030 with an expected annual average growth of around 2,6\%. Basic assumptions behind this scenario were that resource consumption in industrialised countries would not decline significantly compared to today, and that the scarcity of resources would not come into effect (Lutz \& Giljum 2009: 38).

Figure 1: Global Resource Extraction 1980 - 2030

Source: SERI/FoE/Global 2000: 2009.

This expected growth triggers exploration into new sources and efforts of turning ,resources' into ,reserves'. Despite increasing expenditures however, the discoveries of major deposits and world-class discoveries have been decreasing since the mid 1990s (Ericsson 2009: 27). Structural reasons for the mismatch between increasing exploration

\footnotetext{
${ }^{1}$ See e.g. the seminal paper written by Solow (1974) and the reflections in 'Journal of Natural Resources Policy' $1 / 2009$.
} 
costs and decreasing new discoveries are of geographical nature: new deposits are found in more remote and challenging regions, and ore grades are continuously declining. The bulk of the Earth's crust is almost out of reach, be it because of environmental constraints, the energy intensity that would be necessary for extraction or because of other associated risks.

International competition for access to resources (e.g., water, land, food) can result in tensions or open conflicts. Furthermore, prospecting for resources in new, far away and fragile environments, such as the Arctic, rainforests, or the ocean floor will also lead to conflicts over property rights. Ongoing efforts to replace some of non-renewable resources with renewables (e.g., crop-based biofuels) will add to pressures on productive land and, hence, increase conflict potential.

In short, meeting the challenges of future demand for natural resources will certainly continue to be accompanied by increasing costs and is associated with risks for industries downstream.

\subsection{Environmental constraints}

The ecological impacts of increasing global resource use are becoming obvious. The limited abilities of ecosystems to absorb the different outputs of economic activities have been addressed e.g. by Stern (2008) and by the UN's Millennium Ecosystem Assessment. This will put further pressure on producing agricultural commodities on arable land.

The ability to extract and produce materials in a sustainable manner has become a concern. The opening of new mines pose opportunity costs for land use and often causes conflicts with agriculture over water issues. Many countries now have started desalinisation programmes for extraction purposes. Urban sprawl, the determining factor for construction minerals, often covers major fertile soils and reduces production capacities for biomass. The expansion of agriculture for the production of non-food biomass, for instance for biofuels, transforms forests and savannahs into cropland with negative consequences for biodiversity and ecosystems. In that perspective, the supply of energy and minerals needs to be put into a systems perspective of material flows and ecosystem services.

The European Commission (Commission of the European Communities 2005) has suggested pursuing a ,double decoupling', firstly between economic growth and the use of natural resources and, secondly, between the use of natural resources and environmental pressure. Intuitively, this is an appealing concept. Such a distinction also follows the argument that has been put forward by Stern and Cleveland (2004): thermodynamic theory explains that a complete decoupling may not be feasible and that energy is required to produce and recycle materials. Thus, availability is essential for enabling economic growth. 
On the other hand, given the manifold environmental impacts, such analytical distinction between availability and growth may lead to narrow conclusions for pursuing pollution-oriented policies for extractive industries only while the real challenge is to arrive at comprehensive concepts for resource-using industries. Evidence from research with combinations of life-cycle-assessment and other tools such as material flow analysis (see below) suggests that in fact variables of the two angles ,materials' and ,environmental pressure' are highly correlated when product groups, industries or economies are analysed (Bringezu \& Bleischwitz 2009: 37f, 141). In a systems perspective one also ought to take into account that the Earth is a closed system for materials and land, whereas the sun constantly provides energy. To counterargue further against prioritising energy and pollution: producing useful forms of energy always requires materials. It thus makes sense to look at resources and their environmental impacts in a comprehensive manner.

Environmental constraints arise across the whole life-cycle of using materials. Thus, while sustainable mining should certainly be an element for comprehensive strategies. But it is essential to put this into the perspective of analysing the processes downstream across the material value chains of goods, i.e. transforming resources into materials, production, consumption, recycling activities and any final disposal. From the life-cycle perspective, all stages of the life-cycle chain offer opportunities to improve material efficiency, reduce waste generation and close the material loops of the economy. In that sense, concepts such as ,material flow analysis' and ,industrial ecology' reveal particular strengths.

\subsection{Resource constraints to the Low Carbon Economy}

The interdependency between energy and materials can be highlighted for the case of resource constraints to the low carbon economy. Most renewable energies ${ }^{2}$ demand $^{2}$ metals for their production, which are - at least partly - critical. Possible constraints comprise the following metals. Infrastructure for renewable energies requires nonrenewable mineral resources for equipment and process installations. Telecommunication and other information technologies, which may contribute to reductions in global travel and transport, depend increasingly on microelectronic devices, which require speciality metals. Taking into account the ambitious climate change policies of many countries, a number of minerals may come under increasing constraints.

Lithium-ion batteries, currently used in electronic devices are expected to play a growing role in future demand for electric cars. Though forecasts in that area are extremely sensitive to public policy programmes on clean cars, a Credit Suisse estimation of annual growth rates in the order of $10 \%$ (McNulty/Khay 2009) seems conservative but robust. This will likely lead to increased extraction activities at a globally limited number of salt lakes, such as those in Bolivia, Argentina and Chile.

2 Biomass might be an exception; however biomass gasification and other related technologies also demand metals for the production of useful energy. 
Photovoltaic cells for solar arrays and LED-dependent energy-efficient lighting ${ }^{3}$ both rely on gallium, a by-product of aluminium. Gallium for such green-tech demand is estimated to exceed current total world production by a factor of six by the year 2030 (Angerer et al. 2009). Future market development for gallium might contribute to enhanced bauxite mining where countries such as Guinea, China, Russia and Kazakhstan are among the top ten reserve holders.

Tantalum, used for capacitors in microelectronics such as mobile phones, pagers, PCs and automotive electronics, is mined mainly in Australia and Brazil. Due to a breakdown of production in Australia in early 2009, the Democratic Republic of Congo has become a major world supplier of tantalum. Militarisation of mining in this country is well documented (Global Witness 2008) and the country is already subject to UN investigations because of illegal trade revenues financing civil war activities.

Precious metals like gold, silver and platinum are increasingly used in microelectronics. Platinum group metals (PGM) also play an important role as chemical catalysts, used for pollution control, such as in exhaust catalysts in cars, or in energy conversion technologies like fuel cells. Fuel cells are a very promising low carbon technology that can also be used in combination with hydrogen as a substitute for oil in the transportation sector; ${ }^{4}$ it may become more important in the future when liquid hydrogen-rich energy carriers, for instance derived from solar power, are used to re-produce power for electric engines (alternatively batteries will be used). PGM mining and refining is concentrated in only a few regions in the world. Platinum is mined in South Africa, and PGM are produced as a by-product of nickel and copper in Norilsk, Russia, and Ontario, Canada. The former is associated with extreme amounts of mining waste, the latter with considerable emissions of sulphur dioxide. The world's platinum resources would not suffice to supply one third of the global car fleet in 2050 based on current fuel cell technologies (Saurat / Bringezu 2009).

This shortlist is not exhaustive; further critical metals are e.g. copper and chrome, the latter being important for high-tech steel. In addition, phosphorus is a critical substance because it cannot be substituted at today's knowledge and is essential for all nutritional processes on Earth (Cordell et al. 2009) - which is again a constraint on producing agricultural goods in the future and biomass strategies.

As a result of this growing demand and concerns related to scarcity, a material leakage will have to be minimized and strategies of reuse will have to play a larger role. Any such strategies will have to include collection systems for consumer goods that are currently internationally traded and thus open loop systems.

LED stands for light-emitting dioxide.

See e.g. the European Fuel Cell and Hydrogen Joint Undertaking at: http://ec.europa.eu/research/fch/index_en.cfm and the World Hydrogen Conference at: http://www.whec2010.com 


\subsection{Misallocation and uneven patterns of use}

Because environmental constraints have only been incorporated into prices to a very limited extent, this non-internalization of negative externalities leads to distortions and misallocation. Globally, two thirds of the world population use on average between 5 and 6 tons of resources per capita; industrialised countries use twice or more the amount of resources per capita than developing and emerging economies. An average European uses about four times more resources per capita than inhabitants of Africa and three times more than in Asia.

The level and patterns of resource use differ across countries. With an average of roughly 15 tons per capita according to the most commonly used indicator ,Direct Material Input', residents of the EU-27 use about half the resources compared to citizens of Australia, Canada and the United States, but about $25 \%$ more than Japan and Switzerland. Within the EU-15 per capita consumption varies between $45 \mathrm{t}$ per capita (Finland) and 14t per capita (Italy) - a significant difference. Highly uneven patterns are also to be found in Asia. While a Bangladeshi consumes around 1,2 $\mathrm{t}$ of materials every year, resource use is at the order of $45 \mathrm{t}$ per capita in small and rich oilexporting countries such as Bahrain. China is currently estimated to consume materials in the order of 6,5 t per capita. In many medium and high-income countries such as South Korea, Israel, or Saudi Arabia, annual consumption is in the order of $15 \mathrm{t} / \mathrm{per}$ capita, only slightly lower than the OECD average (Giljum et al. 2010: 3).

It is interesting to note that some large economies experienced a modest decrease in the direct use of resources between 1992 and 2005. These include Germany, France, the United Kingdom, the Czech Republic and Sweden. It is also worth noting that Japan experienced the highest (22\%) reduction in resource use per capita. Norway, Canada and Switzerland also reduced their figures from 1992 to 2005.

\section{Measurement of Resources: Material Flow Analysis}

Material Flow Analysis (MFA) was created a few years ago to analyse the use of natural resources in societies (fig). It measures and analyses the flow of materials, energy and water across the system boundaries between the natural environment and the human sphere. It is associated with concepts such as ,industrial ecology' and the ,socioindustrial metabolisms'. Integrating the stages of production, consumption and recycling, it goes beyond traditional resource economics and offers a comprehensive perspective for resource policy. Since Eurostat (2004) and OECD (2008) have provided handbooks on the measurement of material flows, and do in fact promote the collection of data and use of MFA concepts, there are many opportunities for international economics and economic policy to integrate MFA into their models and empirical analysis.

Figure 2: Economy-wide material balance scheme 
Source: OECD 2008.

Direct Material Input (DMI) measures the input of materials that are used in the economy, that is, domestic extraction used (DEU) plus physical imports. Direct material consumption (DMC) accounts for all materials used by a country and is defined as all materials entering the national economy (used domestic extraction plus imports $=$ DMI) minus the materials that are exported. In economic terms, DMC reflects consumption by the residents of a national economy. In contrast, the Total Material Requirements (TMR) and Total Material Consumption (TMC) also account for the indirect resource use that is associated with producing goods for a certain economy including their ,ecological rucksacks' that account for the unused earth masses moved during extraction and production processes. Both the European Commission and OECD aim at integrating the more inclusive indicator TMR/TMC in their accounting schemes and headline indicators.

Sustainability research has revealed that measuring the material flows can also account for main environmental pressures, in particular for generic pressures stemming from the system turnover related to the input side of economies. ${ }^{5}$

\section{General Trends of Resource Productivity}

As a general trend, material productivity ${ }^{6}$ (GDP generated per ton of DMC) in Europe has improved - economies have been creating more value per ton of resources used. Resource productivity in the EU-27 was highest in the United Kingdom, France, Malta, Italy, Belgium and Luxemburg, Germany and Sweden (in 2005). It was the lowest in countries such as Bulgaria, Romania, Estonia, Czech Republic and others. In total, the difference in performance across European economies mounts up to a factor of 17 between top performers and low performers.

Figure 3: Material productivity performance across European economies

Source: Schepelmann et al. 2009

The large economies in this group have also experienced a fairly high increase in material productivity. All the remaining European countries were either around (the Netherlands and Austria) or below the EU-27 average of 1,700 USD/ton DMC.

To put this into an international perspective: material productivity in Switzerland was 3000 USD/ton, in Japan 2600 USD/ton, and in Norway 2000 USD/ton (in the year

Evidence from EU projects such as INDI-LINK, CALCAS, Sustainability A-Test, MATISSE, FORESCENE; see also Bringezu/Bleischwitz 2009, chapter $2 .$.

6 We use the term material productivity if the denominator is DMC or DMI and resource productivity for the more inclusive measurement approaches with TMR/TMC and for general purposes. 
2005). The United States, Canada, Australia and New Zealand had lower material productivity than the EU-27 average - although higher than the average for the EU-12 group.

The growth in material productivity was fastest in the new EU member states, ranging from more than $50 \%$ for Latvia, Poland and the Czech Republic to $122 \%$ for Estonia from 1992 to 2005. A growth of material productivity between $30 \%$ and $50 \%$ occurred in the United Kingdom, Slovakia, Germany, France, Sweden, Ireland and Belgium with Luxemburg.

It is interesting to note that the gap in material productivity between the EU's new member states and old member states has not changed significantly since the early 1990ies. In 2005 material productivity in the EU-12 was only $43 \%$ of the average for the EU-15, while in 1992 the same ratio was 41\%. With the exception of Malta, material productivity in the new member states was well below EU-27 average.

Despite continuous improvements, growth in the productivity of material resources in the EU has been significantly slower than growth in the productivity of labour and, to a lower degree, energy productivity. Over the period 1970-2005, productivity of labour increased by $140 \%$ in the EU-15, while productivity of materials grew by $90 \%$ and productivity of energy increased by 55\%. In the EU-12, where a much shorter time series is available, productivity of materials increased by less than 30\% between 1992 and 2005, whereas productivity of energy and labour grew hand in hand increasing by $65 \%$. This surely reflects also a shift in using energy fuels as well as shifts in imports.

Figure 4: Productivity of Labour, Materials, and Energy across Countries

Source: Eurostat statistics; International Energy Agency

Probably, a main driving force has been the relative pricing of these three inputs and the prevailing tax regimes, which make labour costs more expensive and has led to a focus on labour costs. Despite the high potential for improving material and energy productivity, most macro-economic restructuring and fiscal reform programmes in recent years tended to focus on reducing labour costs. Notwithstanding the pros and cons of this approach, improving material efficiency deserves more attention as a key to reducing costs and increasing competitiveness.

During the period 1980-2005, material productivity in the EU as a bloc was markedly and consistently lower than in Switzerland and Japan (and to some degree behind Norway although the gap has been closing in recent years). There was also a notable gap between the EU 15 and the EU-12, with the material productivity in the latter group lagging behind Australia, Canada and the United States. However, it was a very wide spread within the EU itself, with an order of magnitude difference in resource efficiency between the United Kingdom (ahead of Japan) and Bulgaria and Romania. 
Figure: Changes in Material Productivity 1980 - 2004 across Countries

Source: DMC data from Eurostat and OECD, GDP data from Total Economic Database at University of Wageningen

Driving forces for such uneven patterns of use and slow productivity dynamics certainly deserve more attention by research. Some general explanatory factors behind such development are the stages of development - in particular the intensity of use during early industrialisation stages - and income. However, major differences also occur across countries with similar levels of industrialization and income. Driving forces for resource productivity thus have to be analysed from a perspective that takes into account relevant socio-economic variables of economies and their innovation systems such as

- Construction activities such as new dwellings completed, road construction, share of construction in GDP,

- Structure of the energy system (a high share of coal and lignite correlates with higher TMR and DMC, efforts to increase energy efficiency correlate with resource productivity),

- Imports and international trade: tentative evidence suggests a positive correlation between high imports and material intensity for industrialized countries. The reason probably lies in global production chains, where raw materials and intermediate goods are imported, transformed into finished products domestically and also traded globally, i.e. most industrialized countries utilize the international division of labour as net importers of natural resources. ${ }^{7}$ By contrast, there is a positive correlation between high imports and resource productivity for many less industrialized countries, which is probably due to the competitive pressure on inefficient and resource-intensive domestic industries in those countries.

\section{Resource Productivity, Competitiveness and Innovation}

Our approach challenges traditional economic analysis that has determined natural resources as a factor of production and, hence, assumes that negative impacts on growth could occur if the supply of natural resources is constrained. In contrast we propose that regions - and in particular resource-poor regions - may benefit from increasing resource productivity, at least with regard to their import dependencies and costs to purchase commodities and probably also with regard to innovation. In line with our approach, research has demonstrated that resource-rich Developing Countries may experience their abundance of natural resources as a curse that hinders economic

\footnotetext{
7 Test statistic for EU-15, 1980-2000: an increase in the import share by 1\% would raise the DMC per capita by $0.225 \%$. Research done by Soeren Steger, see Bleischwitz et al. 2009; see also: Dittrich 2009.
} 
diversification, investments in human capital and democracy and, thus, lead to lower growth rates compared to other countries (Gylfason 2009). In line with the chapters above our approach enables research to looking at development across economies and industrial sectors in connection to social, institutional and ecological factors, in particular to emerging markets for eco-innovation.

Our thesis is close to what is called the Porter hypothesis on first mover advantages for countries with an active environmental policy, but focuses stronger on market development and resources. In line with Porter, we also underline the assumption of ecoinnovation effects to compensate for related investments. But global analysis of resources and material flows goes beyond Porter's scope because

- It explicitly addresses international distortions resulting from resource constraints and negative externalities namely in the fields of extraction and recycling (see above), and

- It emphasizes the need for international policy approaches rather than assuming an international diffusion of national environmental policies.

Since our approach covers all natural resources used in economies a guiding question for any green growth is whether and to what extent companies, industries and economies can enhance their prosperity through improvements in resource productivity (see also Weizsäcker et al. 2009).

To test our thesis of a positive correlation between resource productivity and prosperity, we use data on the index of competitiveness as measured by the World Economic Forum and on the Domestic Material Consumption for 26 countries. Our results suggest that there is a moderate positive relationship between the material productivity of economies (measured by GDP in purchasing power parity [PPP] US\$ per kg DMC) and the score value of the growth competitiveness index (GCI) (Fig. 5). The higher the level of material productivity the higher the level of competitiveness (R-squared of 0,3$)$. The usual test statistics was performed; both the t-statistics and the F-statistics are in the 95 $\%$ significance level, while heteroskedasticity was rejected using the Breusch-Pagan test and the White test. However Finland and Italy illustrate exceptional cases where a high value in one indicator is accompanied by a low value in the other indicator.

Figure 5

Source: Bleischwitz et al. 2009; research done by Soeren Steger.

Further evidence suggests that the correlation between competitiveness and resource productivity has not been increasing since 2001 on a broad scale, despite high raw material prices and resulting efforts to use resources more efficiently. A strong correlation however has been found between the MEI-index of competitiveness (macro- 
economic institutions) and European energy productivity performance (R-squared of 0,76, Osnes 2010: 31).

Thus, more research is needed; time series analysis with co-integrated panel data is probably a suitable methodology to deliver robust results on the causality between different drivers for competitiveness and resource productivity. In such research, critical variables are as follows:

- Relevance of material costs for industry: research needs to clarify the total value of resources and track raw material costs along value chains:

- Importing costs for raw materials and semi-finished goods are a key variable for the competitiveness; for the EU, the value based share of the top-ten raw material imports in total imports grew between 1998 and 2004 from around $8 \%$ up to $13 \% .^{8}$

- Data provided by the German Federal Statistical Office reveal that the costs of materials in Germany account for around $40-45 \%$ of the gross production value of manufacturing companies (this includes purchased material inputs such as raw materials and intermediate goods). These data is based upon a questionnaire to industry managers and, hence, is relevant for industries but can hardly be added up to an aggregated figure for whole economies.

- Since most commodities are purchased on a US-Dollar basis, the exchange rate becomes quite relevant. Currently, the financial crisis has weakened the position of the Euro versus the US-\$, which will lead to more extreme price increases for energy and metals in Europe compared to the US.

○ The macroeconomic situation - characterized by increasing public debts - increases the vulnerability of economies towards higher commodity prices for raw materials. This may encourage resource savings because such strategy lowers risks of inflation caused by importing fuels and commodities, and it may also favour resource taxation.

- It is also worth mentioning that the competitiveness indicators do not capture negative externalities. Countries investing in eco-innovation might earn the benefits at a later point in time, whereas countries with dumping practices and weak environmental standards can gain short-term benefits by lowering production costs at the expense of others.

- The awareness among managers and companies to pursue material efficiency is still relatively low. Rennings and Rammer (2009) found that just $3 \%$ of German companies have reported significant undertakings to increase material efficiency in their analysis of the EU Community Innovation Survey (CIS). However sales

\footnotetext{
${ }^{8}$ Based on Eurostat and 10 minerals, but no semi-final goods; the share actually is higher than the analysis of de Bruyn et al. (2009) suggests.
} 
per employee in those companies are approximately $15 \%$ higher than in average industries. These findings indicate a gap between current awareness and potential benefits that needs to be tested by more in-depth research at an international scale.

The vast majority of innovation can currently be characterized as process innovation, a strategy that offers affordable risks for companies compared to product innovation or system innovation. ${ }^{9}$ Such process innovation becomes visible in material efficiency when companies accomplish strategies such as ,zero losses', ,design to costs', or ,remanufacturing'.

At an international scale however, an advanced process innovation of closing the loops in international value chains remains a challenge especially when end-of-life stages of consumer goods are considered. A 3R strategy for metals, which could be applied in the product groups of mobile phones and vehicles, requires further efforts and interlinkages between different types of innovation, including institutional change and political action in those countries where the used products are imported. According to Eurostat, the EU exports end-of-life vehicles predominantly to countries such Kazakhstan, Guinea, Russia, Belarus, Serbia, Benin and others.

For that reason it will become important to complement producer responsibility with materials stewardship. In this regard and because only a limited number of industrial sectors require a significant share of the total resource requirements of the economy, ${ }^{10}$ a sectoral approach to innovation (Malerba 2007) is useful to pursue. In such a perspective, new business models for base metal industries might emerge (Petrie 2007), which could position the industry at the heart of material value chains. This is a horizontal task, which clearly transcends vertical production patterns, for example, along the automotive chain. Within networks and partnerships of integrated material flows management, the base metal industry can demonstrate stewardship and leadership. The challenge is to overcome the business model of a primary production company delivering basic materials and develop competences towards a fully integrated material flow company network, with high knowledge intensity, customer orientation, worldwide logistics, high-level recycling and a long time horizon. Such base metal companies will manage products, flows and stocks.

In total, resource productivity underlines a new category of innovation that can be characterized as "material flow innovation". It captures innovation across the material value chains of products and processes that lower the material intensity of use while increasing service intensity and well-being. It aims to move societies from the extract, consume, and dispose system of today's resource use towards a more circular system of material use and re-use with less resource use overall. While the established categories of process, product and system innovation (and organisational and advertising innova-

\footnotetext{
${ }^{9}$ See also the paper written by Tomoo Machiba.

10 In Germany, ten sectors induce more than 75\% of the TMR; see Acosta et al. 2007.
} 
tion, see e.g. the OECD Oslo Manual on Innovation) have their merits, the claim can be made that given the pervasive use of resources across all stages of production and consumption a new category will have to be established to capture innovation activities which include

- Developing new materials with better environmental performance;

- Substituting environmentally intensive materials with new materials, functionally new products and functionally new services leading to lower demand;

- Establishing life-cycle wide processes of material efficiency e.g. by sustainable mining, more efficient production and application of materials and strategies such as

- Enhancing re-use and recycling

- Recapturing precious materials from previously open loop systems (e.g. critical metals, phosphorus)

- Functionally integrating modules and materials in complex goods (e.g. solar cells integrated in roofs)

- Increasing the lifetime and durability and offer related services

- Transforming infrastructures towards a steady-state stocks society e.g. via improved maintenance systems for roads and buildings as well as developing new resourcelight buildings and transportation systems and other network goods (such as waste water systems) and, in the long run, establishing a solarised technosphere for dwellings and other systems of provision (S. Bringezu 2009).

Such a perspective on innovation and green growth is also consistent with lead markets worldwide. In distinction to prevailing climate change diplomacy, where it is difficult to engage the emerging economies, our perspective sheds light on attractive lead markets in emerging economies because they can build upon advantages from their natural endowments and allow for the establishment of new development pathways.

\section{Resource Policies: Strategic Pillars and Incentives}

Innovation and lead market perspectives are however faced with barriers and market failures (Bleischwitz et al. 2009: 228ff); policies will be needed to manage the ensuing transition processes. Corresponding policy objectives are unlikely to be delivered by one single instrument alone. One of the key conclusions of various strands of research is that a well-designed mix of institutional change and policy instruments is better capable of governing transition strategies than single instruments (Smith et al. 2005, Bleischwitz 2007). ${ }^{11}$

Figure: Resource Policy

Source: Bleischwitz et al. 2010

${ }^{11}$ See also the contribution by Rene Kemp and Paul Ekins in this issue. 
Better information is crucial for sustainable resource management, especially for improving material efficiency at the business level. The issue is not the supply of information alone, but the dissemination and appropriate application of such information in daily business routines.

Public programmes to promote material efficiency and resource productivity can help to improve the information base, especially in SMEs, and facilitate market entry. The German Material Efficiency Agency, the regional eco-efficiency agency of North Rhine-Westphalia and the UK Resource Efficiency Network have demonstrated good success in approaching companies and disseminating know-how on promoting material efficiency.

From a mid-term perspective, the establishment of an international database and data centre on the resource intensity of products and services is needed (Bleischwitz et al. 2009: 241ff). The main objective of an international database is to provide users with validated, internationally harmonised and periodically updated data on key resources, the resource intensity and related key indicators of raw materials, semi-manufactured goods, finished products and services. Following the slogan ,no data no market, such data facilitates a sustainable management of material flows in value chains and economies and a dematerialisation of currently unsustainable production and consumption patterns. Over time, such an international database should also offer data on indirect resource flows as well as data on material cost structures of industries.

A regulatory perspective should be emphasised. Clear long-term signals, credible commitments and strong incentives need to be given from policies. Economic incentives can play a key role by triggering markets towards eco-innovation. Taxes have the advantage of being implementable by individual governments without international agreements. All taxes are controversial, but those on recognised 'bads' such as tobacco, alcohol or carbon emissions may be less so than others and allow the balance of taxes to be adjusted away from others, such as on income and labour.

Towards the model of a ,Material Input Tax', which offers theoretically convincing but less operational advantages, a real world proposal is on taxing construction minerals. Following a tax on aggregates that has been successfully implemented in the UK (EEA 2008), a construction tax could address basic materials such as sand, gravel, crushed rocks and start from a level that is approximately $30 \%$ above market price, with a stepwise increase of $3-5 \%$ p.a. The objective is to facilitate recycling and innovation - including system innovations such as resource-light construction and functionally integrated building envelopes. Besides the intended steering effect, parts of the revenues could also be used to finance innovation programmes in such direction.

A combination of information-based, knowledge generating incentives supported by a pricing policy can be seen as a strong momentum for increasing resource productivity. Other instruments such as standard setting may add to this. It will be important to 
address the international level. In this case, a 3R policy will have to address open trade for critical metals and recycling (OECD 2010) as well as to facilitate action by establishing an international contract (,covenant') on closing material loops for resourceintensive consumer goods. Such a covenant might include the main countries of production and final consumption of vehicles and electronic devices, and establish principles of materials stewardship, certification and responsibility. While providing investment opportunities and stability, it may also offer incentives for Developing Countries to join. Furthermore, an international agreement on sustainable resource management is deemed necessary in the long run (Bleischwitz et al. 2009).

\section{Conclusions}

Our paper emphasizes the transformation to a green economy that comes along with resource constraints and increasing resource productivity. It puts the need to limit and lower the emissions of greenhouse gases in the wider context of managing ecosystems and natural resources in a sustainable manner while acknowledging the prospects for eco-innovation and green growth. The claim is made that this offers a comprehensive view on possible resource constraints as well as on tangible business opportunities, in particular if policies act as a, visible hand'. This means that policies should provide a long-term orientation, essential information and sound economic incentives, complemented by international cooperation. Regarding the latter, our paper proposes an international covenant to establish material stewardship for metals and an international agreement on sustainable resource management.

However more research ought to be done to understand and explore the international economics of such transition strategies and its interdisciplinary dimensions. Research needs to conduct time series analysis to establish causality on drivers for resource use and competitiveness as well as to explore the relevance of lifecycle material costs across different industries and economies. In that regard, international economics and economic policy are entering a fascinating field.

\section{References}

Aghion, P. / Hemous, D. / Veugelaers, R. (2009): No green growth without innovation, Bruegel Policy Brief No. 7, Brüssel.

Angerer, G., Erdmann, L., Marscheider-Weidemann, F., Scharp, M., Lüllmann, A., Handke, V. und Marwede, M. (2009) Rohstoffe für Zukunftstechnologien. Stuttgart: Fraunhofer IRB Verlag.

Bleischwitz, R. (Ed. ) (2007): Corporate governance of sustainability: a co-evolutionary view on resource management; Cheltenham [u.a.]: Elgar.

Bleischwitz, R. / Welfens, P. / Zhang, ZX. (Ed.) (2009): Sustainable Growth and Resource Productivity Economic and Global Policy Issues, Greenleaf Publisher. 
Bleischwitz, R. et al. (2009): Outline of a resource policy and its economic dimension, in: Bringezu, S. I Bleischwitz, R. (Eds.): Sustainable Resource Management. Trends, Visions and Policies for Europe and the World, Greenleaf Publisher, pp. 216-296.

Bringezu et al. (2009): Europe's resource use: basic trends, global and sectoral patterns, environmental and socio-economic imapcts, in: Bringezu, S. / Bleischwitz, R. (Eds.): Sustainable Resource Management. Trends, Visions and Policies for Europe and the World, Greenleaf Publisher, pp. 52 $154 .$.

Bringezu, S., 2009. Visions of a sustainable resource use. In Sustainable Resource Management. Trends, Visions and Policies for Europe and the World. Greenleaf, S. S. 155-215.

Bringezu, S. \& Bleischwitz, R., 2009. Sustainable resource management : global trends, visions and policies, Greenleaf.

Commission of the European Communities, 2005. Thematic Strategy on the Sustainable Use of Naural Resources.

Cordell, D., Drangert, J.-O., and White, S., (2009) The Story of Phosphorus: Global food security and food for thought. Global Environmental Change, 2009. 19(2009): p. 292-305.

De Bruyn, S. / Markowska, A. / de Jong, F. / Blom, M. (2009): Resource productivity, competitiveness and environmental policies, CE Delft.

Dittrich, M. 2009. The physical dimension of international trade, 1962-2005. In: Bleischwitz, R., Welfens, P.J.J., Zhang, Z.X. (Eds.), Sustainable growth and resource productivity. Economic and global policy issues, Greenleaf Publishing, Sheffield, UK.

Ericsson, M., 2009. Will the mining industry meet the global need for metals? In Sustainable Growth and Resource Productivity. Sheffield: Greenleaf, S. 14-30.

Eurostat / IFF, 2004. Economy-wideMaterial Flow Accounts and Indicators of Resource Use for the EU-15.

Giljum, S. / Dittrich, M. et al. (2010): Resource use and resource efficiency in Asia. A pilot study and trends over the past 25 years, commissioned by UNIDO, SERI/WI.

Global Witness, “'Faced with a gun, what can you do?”' (London: Global Witness, 2008).

Gylfason, T., 2009. Development and growth in mineral-rich countries. In Sustainable Growth and Resource Productivity. Sheffield: Greenleaf, S. 42-85.

Lutz, C. \& Giljum, S., 2009. Global resource use in a business-as-usual world up to 2030: updated results form the GINFORS model. In Sustainable Growth and Resource Productivity. Sheffield: Greenleaf, S. 30-42.

MacLean, H.L., Duchin, F.,Hagelüken, C., Halada, K., Kesler, S.E., Moriguchi, Y, Mueller, D., Norgate, T.E., Reuter, M.A., van der Voet, E., Hagelüken, C. und Meskers, C.E.M. (2010) Stocks, Flows and Prospects of Mineral Resources, in: Graedel, T., and van der Voet, E. (eds.) Linkages of Sustainability. Strüngmann Forum Report 4. Cambridge, MA: The MIT Press.

Malerba, F., 2007. Innovation and the dynamics and evolution of industries: Progress and challenges. International Journal of Industrial Organization, 25(4), 675-699.

McNulty, J. P. / Khay. A., 2009.:Lithium. Extracting the Details of the Lithium Market. Credit Suisse, p. 18. Available at: http://www.docstoc.com/docs/12415608/Lithium.

OECD (2009): Eco-Innovation in Industry: Enabling Green Growth; Paris: Organisation for Economic Cooperation and Development.

OECD, 2008. Measuring Material Flows and Resource Productivity, Paris: OECD. 
Osnes, M.-A, (2010): Energy Use and Competitiveness. The relationship between energy intensity and national competitiveness, Thesis submitted at the College of Europe Bruges, Belgium.

Saurat, M. and S. Bringezu (2009) 'Platinum Group Metal Flows of Europe: PART II: Exploring the Technological and Institutional Potential for Reducing Environmental Impacts' Journal of Industrial Ecology 13: 406-421.

Schepelmann, P. / Stock, M. / Koska, T. / Schüle, R. / Reutter, O. (2009): A green new deal for Europe : towards green modernisation in the face of crisis ; a report by the Wuppertal Institute for Climate, Environment and Energy. - Brussels : Green European Foundation, 2009 - (Green new deal series ;1).

SERI / FOE / Global 2000 (2009): Ohne Mass und Ziel? Über unseren Umgang mit den natürlichen Ressourcen der Erde, Wien.

Rennings, K. / Rammer, C. (2009): Increasing energy and resource efficiency through innovation - an explorative analysis using innovation survey data. ZEW discussion paper No. 09-056.

Smith, A., Stirling, A. and F. Berkhout (2005) The governance of sustainable sociotechnical transitions, Research Policy, 34, pp.1491-1510.

Solow, R.M. (1974) 'The Economics of Resources or the Resources of Economics', American Economic Review, Papers and Proceedings 64: 1-14.

Solow, R.M. et al. (2009) Special issue on 'The Economics of Resources or the Resources of Economics'), in: Journal of Natural Resources Policy Research 1.1.

Stern, N. (2008): The Economics of Climate Change. American Economic Review, (98.2), 1-37.

Stern, D. / Cleveland, C. (2004): Energy and Economic Growth, Rensselaer Working Papers in Economics, Number 0410.

UNCTAD (2010): Trade and environment review. Promoting the poles of clean growth to foster the transition to a more sustainable economy, Geneva.

Walz, R. (2009): Competences for Green Development and Leapfrogging in Newly Industrializing Countries, accepted for publication in: International Economics and Economic Policy (in press).

World Resources Forum Davos. Declaration of the World Resources Forum - Sept. 16, 2009: Resource Governance - Managing Growing Demands for Material on a Finite Planet, available at: http://www.worldresourcesforum.org, 2009. 
Figure 1: Global Resource Extraction 1980 - 2030
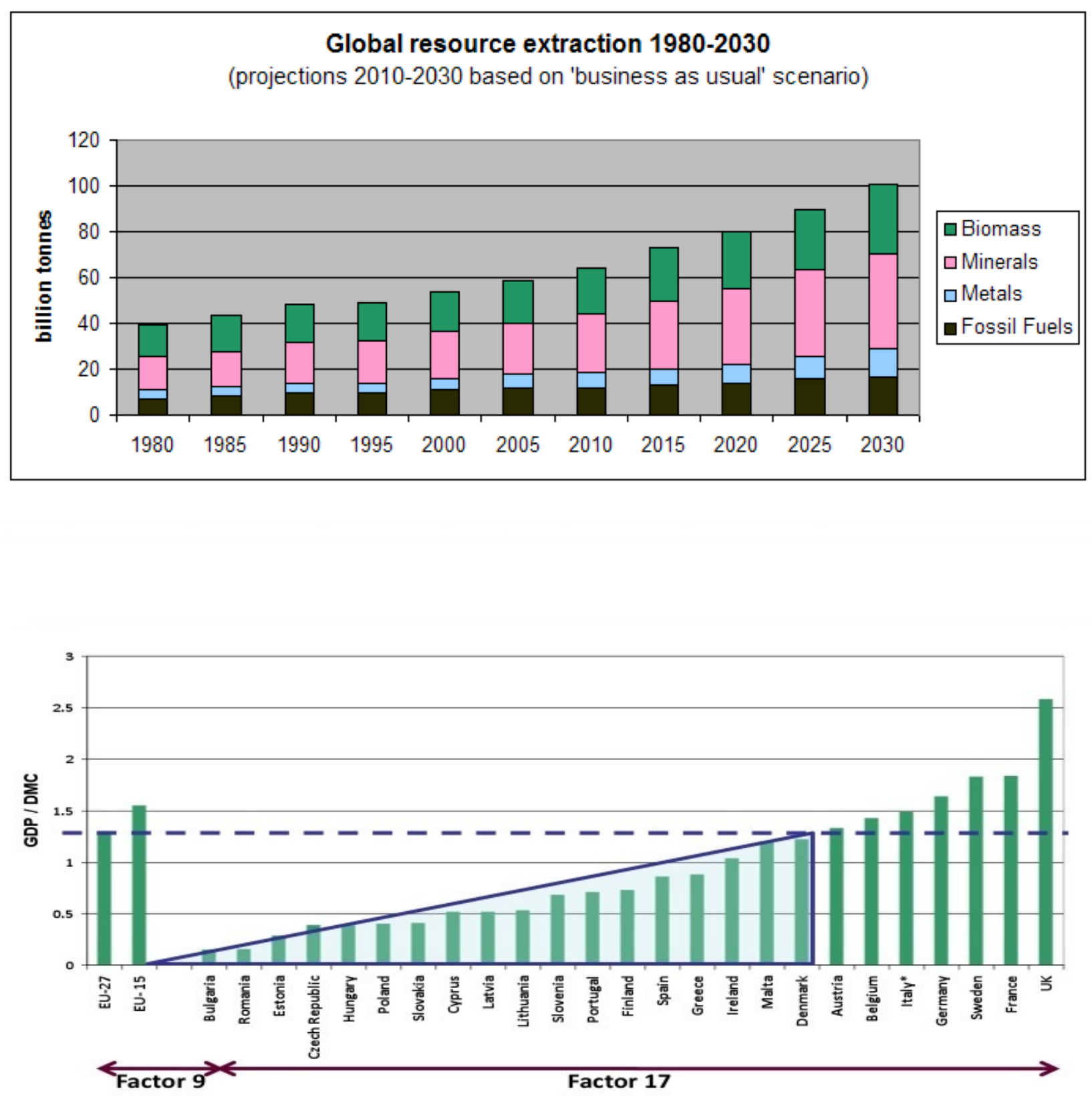
Productivity of labour, material and energy EU-15, 1970-2005

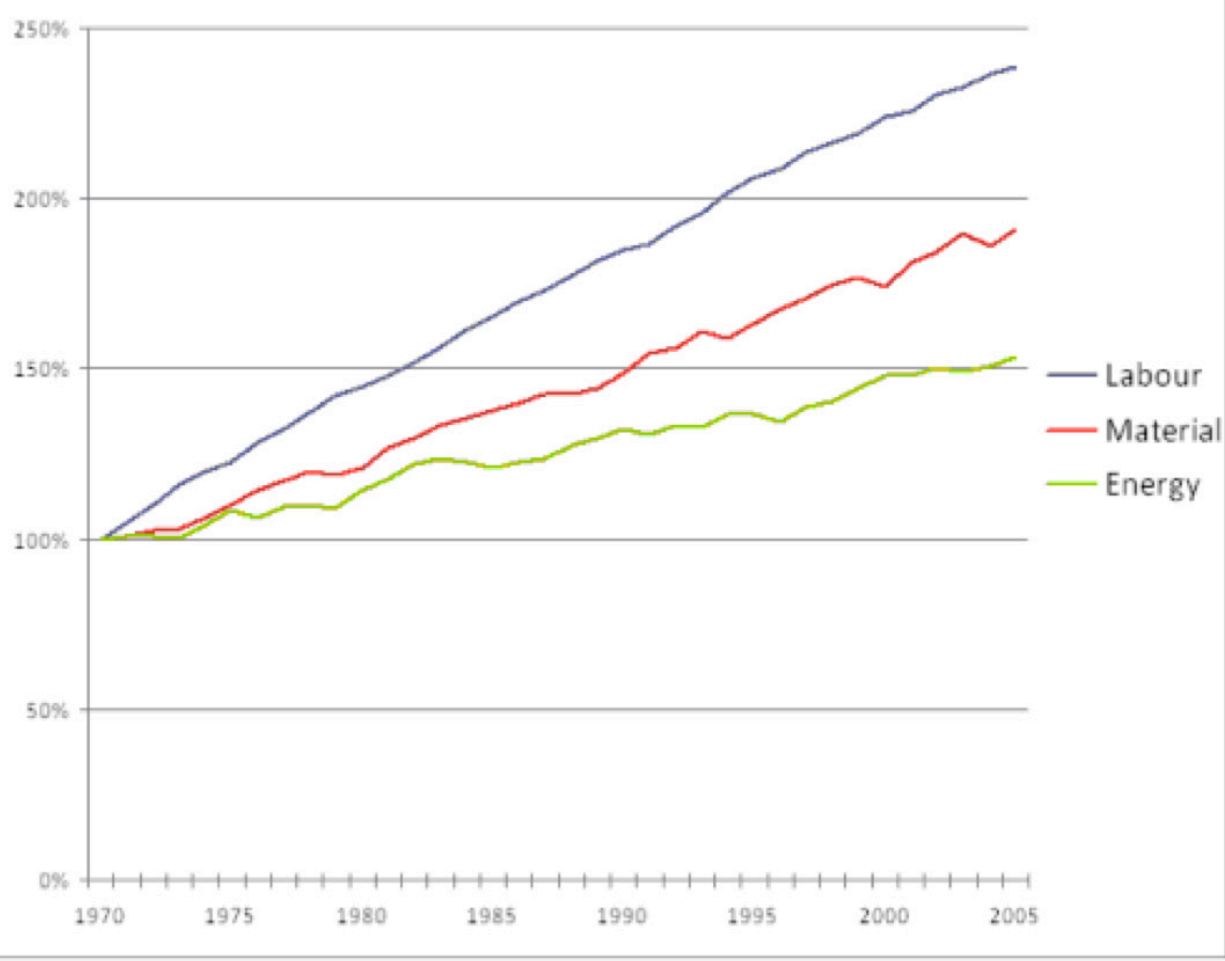

Productivity of labour, material and energy EU-12, 1992-2005

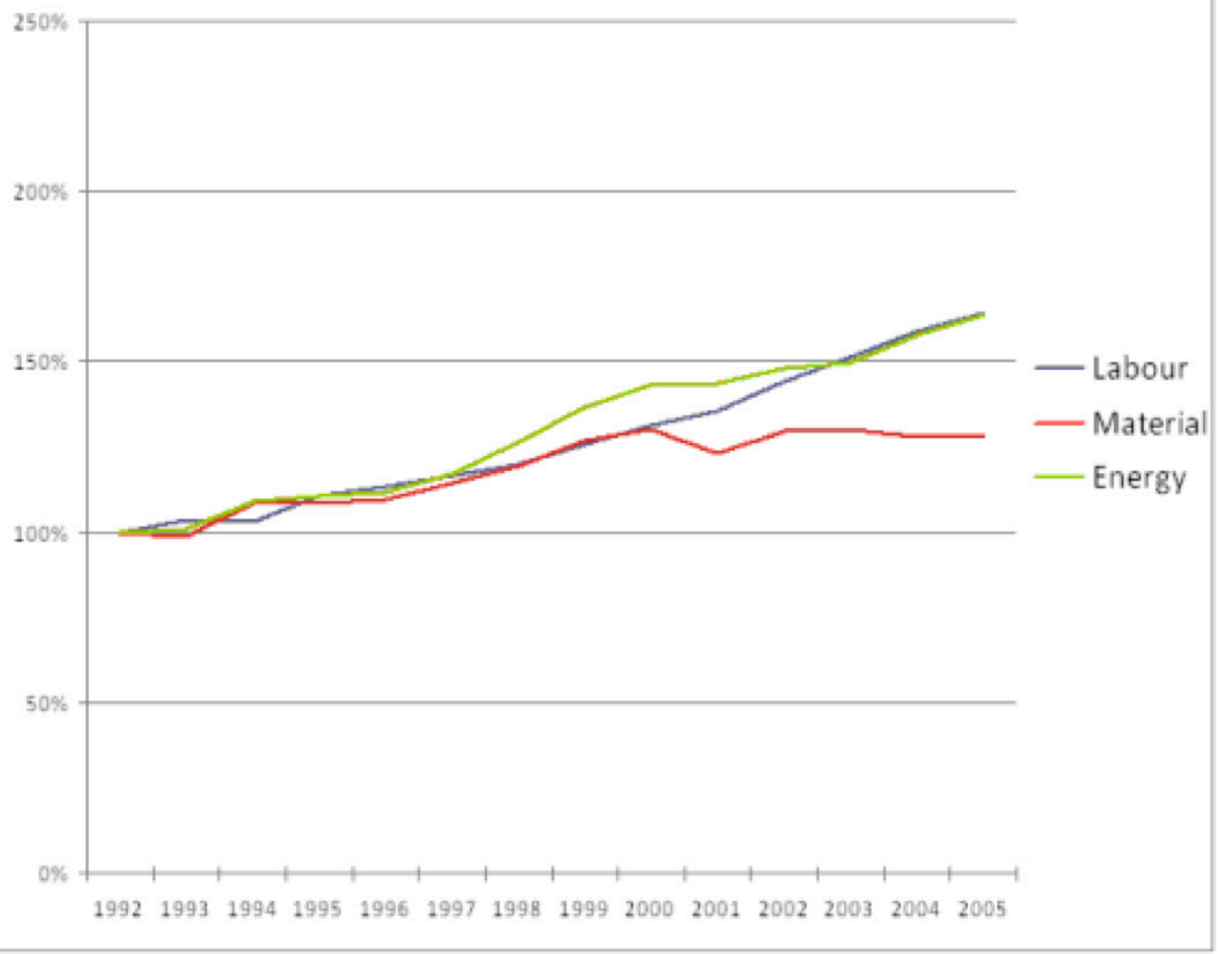


Changes in Material Productivity between 1980 (1992) and 2005

EU15 and EU12 average vs selected non-EU countries

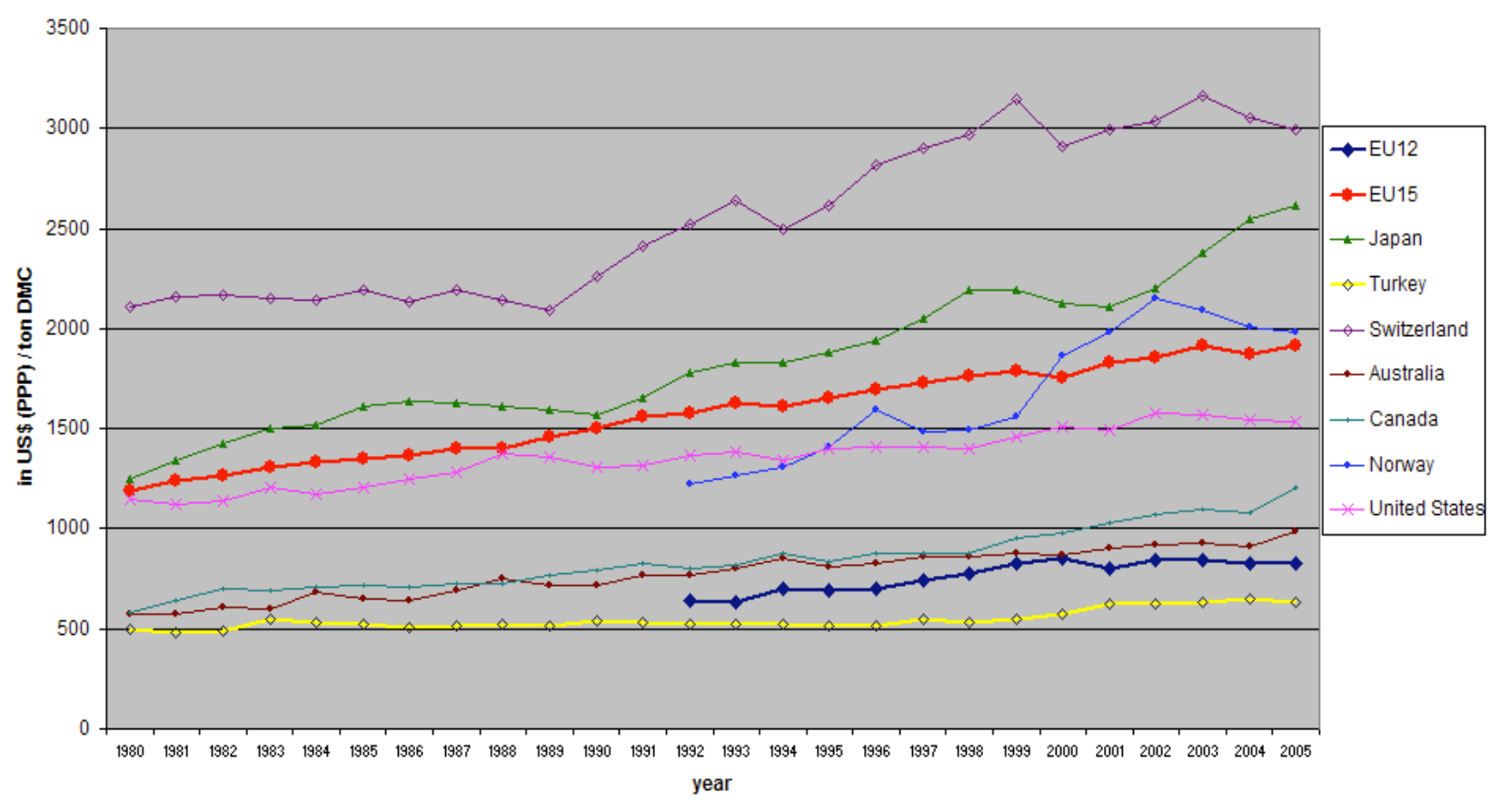




\section{Economy-wide material balance scheme}

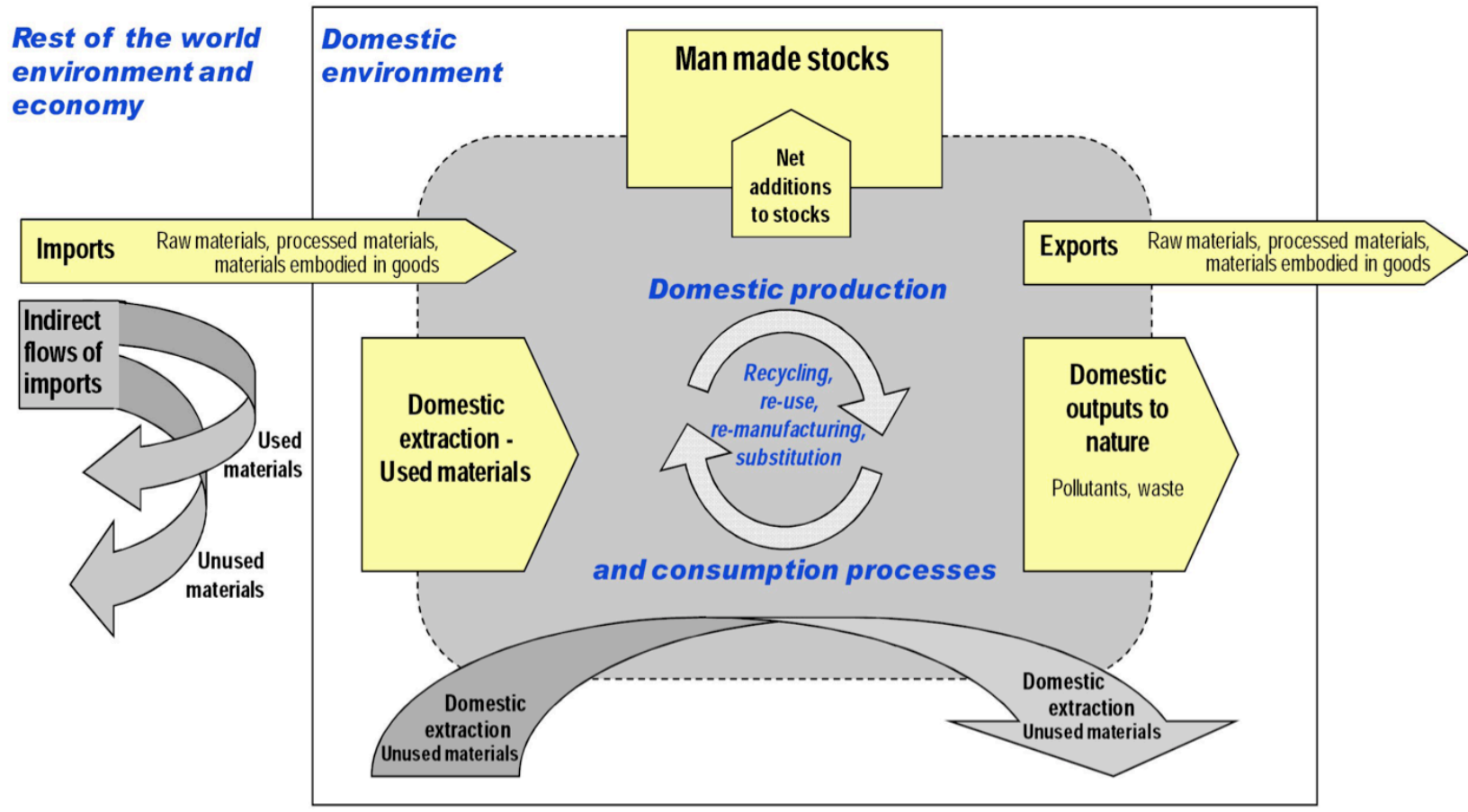

\section{Resource Policy}

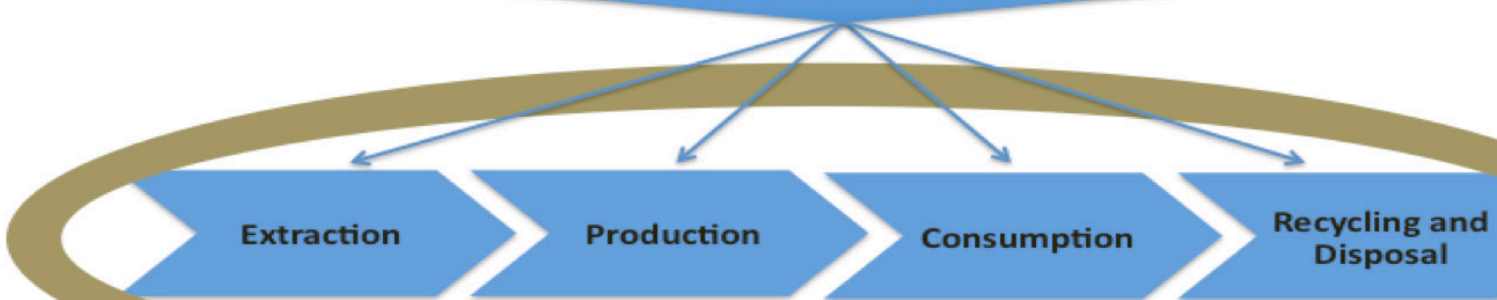

